\title{
DAMPAK COVID-19 TERHADAP PERUBAHAN HARGA SAHAM
}

\author{
*Dewi Anggraini ${ }^{1}$ \\ ${ }^{1}$ Fakultas Bisnis dan Ilmu Sosial, Program Studi Akuntansi, Universitas Dian Nusantara, Jakarta, Indonesia
}

*Email Korespondensi:

dewi.anggraini205@gmail.com

\section{ARTIKEL INFORMASI}

Diterima:

3 March 2021

Direvisi:

15 April 2021

Dipublikasi:

16 Mei 2021

\begin{abstract}
ABSTRAK
Penelitian ini bertujuan untuk mengetahui reaksi pasar modal terhadap adanya pengumuman masuknya Virus Covid-19 ke Indonesia. Data penelitian diambil pada saat pengumuman masuknya Virus Covid-19 ke Indonesia, diberlakukannya kebijakan PSBB dalam rangka menanggulangi pandemic Covid-19, kemudian pada saat pengumuman dijalankannya kembali moda transportasi. Event window yang digunakan dalam penelitian ini adalah 11 hari,dimana 5 hari sebelum dan 5 hari sesudah hari sesudah pengumuman event dan 1 event date pada hari tersebut.Hasil paired sample t-tes, menunjukkan terjadi perbedaan signifikan pada harga saham sebelum dan sesudah diumumkannya kasus pertama covid-19 di Indonesia. Hal ini ditunjukkan dengan nilai signifikasi $0,00<0,05$. Dimana harga saham mengalami penurunan dibandingkan sebelum adanya kasus covid19. Sedangkan pada saat diberlakukannya kebijakan PSBB dan pengumuman dijalankannya kembali moda transportasi, tidak terjadi perbedaan yang signifikan pada harga saham sebelum dan sesudah event tersebut.
\end{abstract}

Kata Kunci: Covid-19, Return Saham

\section{PENDAHULUAN}

Negara-negara di dunia kini sedang dihadapkan pada tantangan besar penanganan wabah virus corona yang secara resmi diidentifikasi oleh WHO sebagai Corona Virus Desease-19 atau disingkat Covid-19. Pandemi yang bermula dari Kota Wuhan, Cina, ini telah menimbulkan global shock karena memang dalam beberapa dekade terakhir belum pernah kita mengalami serangan wabah virus dengan tingkat dan daya tular begitu cepat dan masif seperti virus corona ini, tidak seperti virus SARS dan MERS, serta Ebola yang juga sempat mengacam beberapa tahun yang lalu, namun dengan cepat dapat teratasi.

Sejak kemunculannya pada Desember 2019 lalu pandemi Covid-19 telah menimbulkan dampak yang sangat serius pada hampir seluruh aspek kehidupan manusia di muka bumi. Terutama di sektor ekonomi, meskipun jika dilihat secara objektif pandemi ini juga telah memberi dampak positif terhadap perbaikan kondisi ekologis bumi-dengan skala dan luasan yang tidak main-main: global, worldwide, seluruh negara di dunia merasakannya. Pandemi virus corona pertama kali muncul ke permukaan ketika tanggal 31 Desember 2019 WHO menerima laporan dari negara China bahwa ada wabah di kota pelabuhan Wuhan dari virus yang belum diketahui. Wabah ini meluas dengan sangat cepat ke berbagai negara dalam dua minggu kemudian sehingga menjadi pandemi global. Di Indonesia, total kasus covid-19 positif sebanyak 3,512 orang, dengan jumlah kematian sebanyak 306 orang, dan sembuh sebanyak 282 orang (www.covid19.go.id). Data per tanggal 
10 April 2020, 19.56 PM, persentase kematian yang terjadi di Indonesia (8.71\%) lebih besar dibandingkan persentase kematian yang terjadi di dunia (5.99\%). Persentase yang tinggi ini melahirkan sangat banyak kecemasan dikalangan masyarakat.

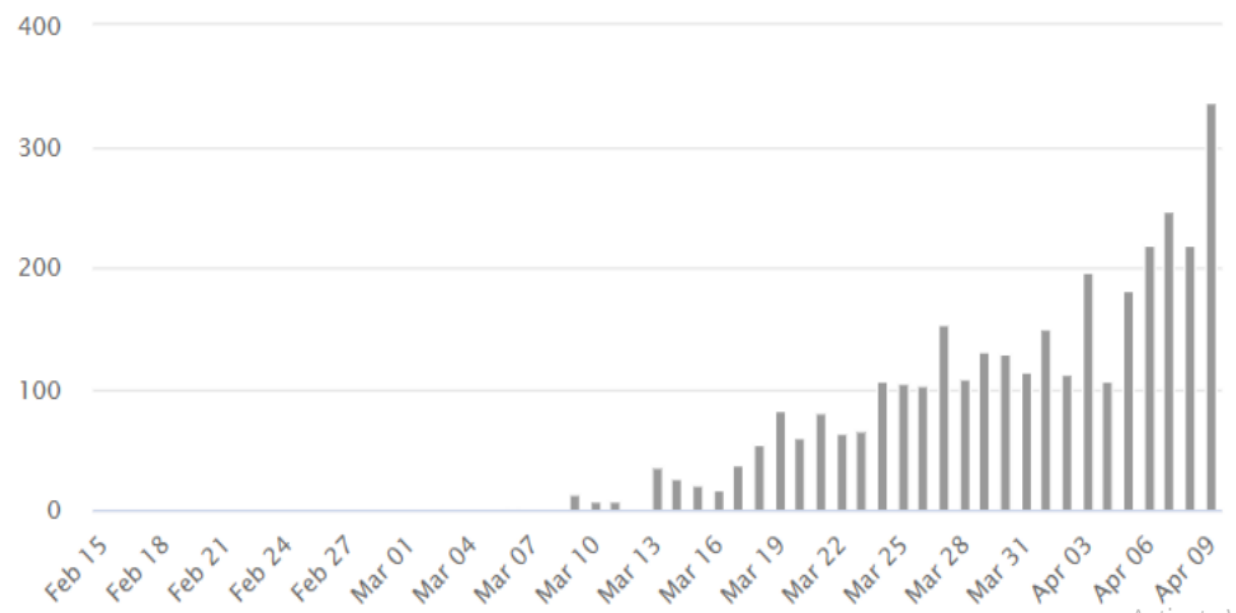

Gambar 1. Jumlah Penambahan Kasus Harian 02 Maret 2020 - 10 April 2020

Sumber:https://www.worldometers.info/coronavirus/country/indonesia/,2020

Grafik di atas menunjukkan bahwa penambahan kasus per hari meningkat dari hari ke hari, tanggal 9 April terdapat pengingkatan kasus terbanyak sebanyak 337 kasus positif dalam sehari. Hal ini pastinya memberikan kerugian yang besar pada masyrakat dan Indonesia. Pengingkatan kasus positif yang terjadi dari hari ke hari menyebabkan banyak kerugian terhadap berbagai sektor di Indonesia. Salah satu nya adalah sektor ekonomi Indonesia. Pandemi Covid19 sudah sangat menghancurkan ekonomi Indonesia. Kasus pertama diumukan oleh Presiden Jokowi pada tanggal 2 Maret 2020. Presiden Jokowi mengumumkan terdapat 2 orang yang positif terkena Covid-19. Pada tanggal 2 Maret 2020, nilai tukar rupiah masih tidak selemah sekarang. Pada tanggal 2 Maret 2020, nilai tukar 1 USD terhadap rupiah adalah sebesar Rp. 14,265.00, per hari ini tanggal 9 April 2020 nilai tukar 1 USD terhadap rupiah adalah sebesar Rp. 15,880.004 . Jadi rupiah melemah sebesar 1,615 poin atau melemah sebesar $11.32 \%$ dalam 39 hari. Pelemahan terburuk rupiah hingga 10 April 2020, terjadi pada tanggal 23 Maret 2020, dengan nilai tukar 1 USD terhadap rupiah sebesar Rp. 16,575.00 atau melemah sebesar $16.19 \%$.

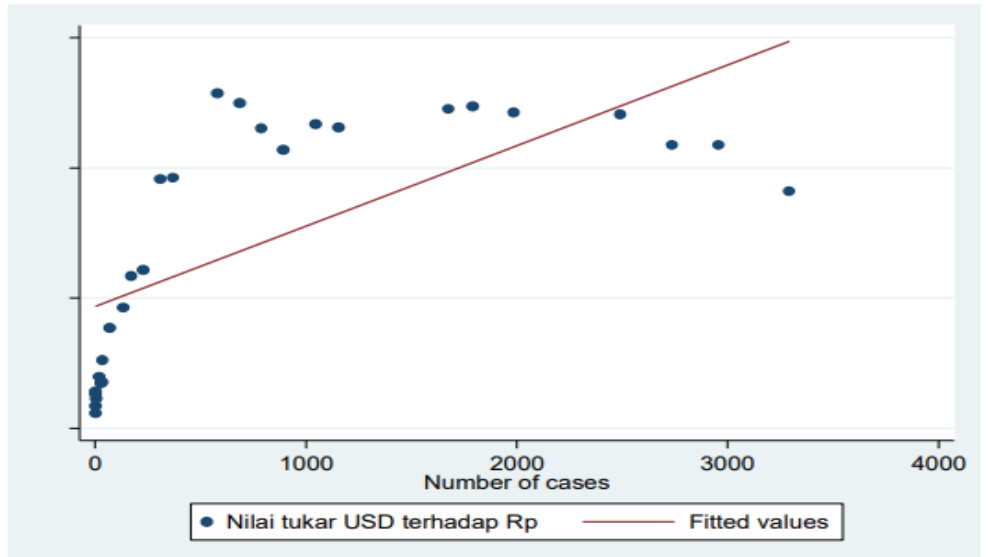

Gambar 2. Pengaruh jumlah kasus Covid-19 di Indonesia terhadap Nilai Tukar Rupiah

(Sumber : Hasil Pengolahan Data, Sihaloho,2020) 


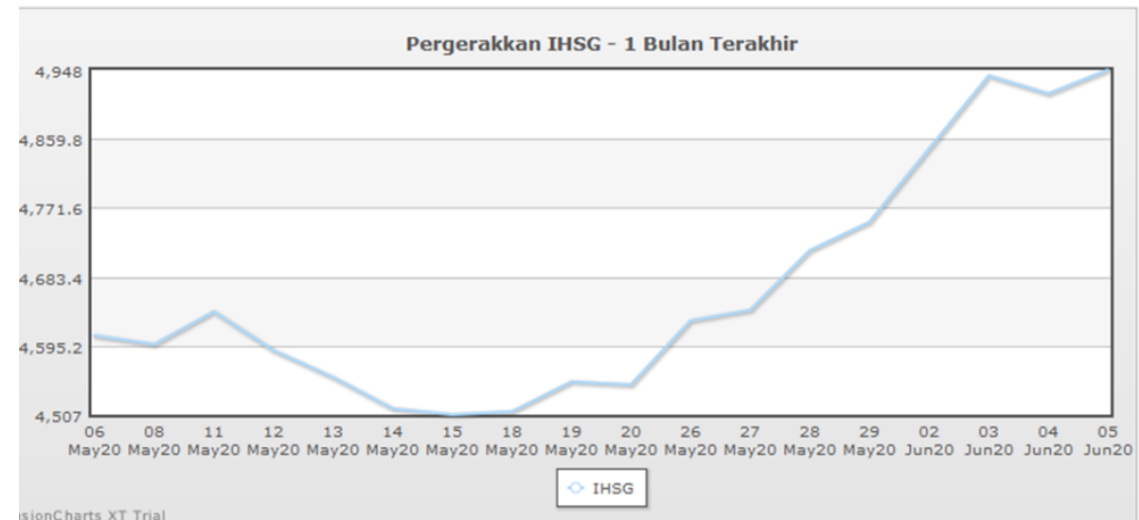

Gambar 3. Grafik Pergerakan IHSG Bulan Mei 2020

(Sumber : https://ihsg-idx.com/)

Hasil pengolahan data menunjukkan bahwa terdapat kecenderungan hubungan positif antara jumlah kasus Covid-19 dengan kekuatan nilai tukar USD terhadap Rupiah. Jika kasus covid 19 selalu bertambah akan memperburuk kondisi perekonomian Indonesia. Salah satu indikator nya adalah terjadinya pelemahan Rupiah terhadap USD dan mata uang asing lainnya. Di Indonesia sektor industri yang paling berdampak atas terjadinya wabah Covid-19 adalah sektor pariwisata. Sektor pariwisata selama ini digadang-gadang sebagai sumber kontribusi devisa terbesar kedua bagi Indonesia. Namun, pandemi Covid-19 mengubah semuanya. Sejak adanya instruksi menjaga jarak sosial dan gaung beraktivitas di rumah saja, sektor pariwisata menjadi lesu. Sejumlah stimulus yang disiapkan pemerintah untuk membangkitkan sektor pariwisata tak mampu membendung dampak negatif corona Covid-19. Atraksi wisata banyak ditutup.

Okupansi mayoritas hotel juga turun drastis dan berarti tak ada pendapatan. Bali adalah salah satu destinasi yang paling terkena dampaknya. Wisatawan mancanegara adalah sumber pemasukan nomor satu dari Pulau Dewata tersebut. Pada bulan Februari 2020, sebanyak 392.824 wisatawan datang ke Bali, menurut Kantor Imigrasi Bali dan angka ini turun sebesar 33\% sejak bulan Januari akibat virus corona. Jumlah penghuni hotel di Bali turun sampai 70 persen sejak virus corona menyebar dan hal ini berpengaruh terhadap kesejahteraan para karyawan. Dampak virus corona pada ekonomi tidak bisa dihindari. Maka dari itu, beberapa karyawan hotel di Bali hanya dibayar setengah gaji. Pemotongan ini diperlukan agar usaha tetap berjalan namun juga menjaga kebutuhan ekonomi para karyawan. Beberapa manajemen hotel juga meminta para perkeja mereka untuk cuti saat sedang sepi.

Pada sektor industri rokok, Gabungan Pabrik Rokok (Gapero) menyatakan pandemi virus corona (Covid19) turut memberikan dampak bagi industri rokok, khususnya terkait pada aktifitas produksi dan penjualan produk rokok, namun pabrikan tetap harus menjalankan produksinya saat masa pandemi, masih terus melakukan kegiatan usaha. Sehingga masih tetap menyerap tenaga kerja dan menggerakkan perekonomian masyarakat. Disaat beberapa sektor industri mulai tumbang akibat wabah covid-19, sektor barang konsumsi (consumer goods) mampu menjadi sektor yang paling minim koreksi. Berdasarkan data PT Bursa Efek Indonesia, kinerja sektor consumer turun 19,17 persen sepanjang kuartal I/2020. Penurunan itu merupakan yang paling tipis dibandingkan sektor lainnya. Consumers goods as predicted, yaitu sektor yang paling defensif alias yang mampu bertahan saat resesi dan krisis tetapi tidak bisa grow tinggi juga saat ekonomi booming. Adanya pandemi corona dan imbauan untuk berkegiatan dari rumah menyebabkan konsumsi barang masyarakat meningkat, kemungkinan menjadi salah satu sentimen positif yang menyokong kinerja sektor consumer.

Berdasarkan data Bloomberg, saham PT Siantar Top Tbk. (STTP) menjadi penopang untuk sektor barang konsumsi dengan kenaikan 44,44 persen sepanjang Q1/2020. Kemudian ada pula saham ITIC (40,38 persen) dan $\operatorname{INAF}(24,14$ persen) dan KAEF (4,80 persen). Kehadiran dua emiten farmasi ini dinilai tidak mengherankan karena keduanya memang memang produsen produk kesehatan serta obat dan vitamin yang kini banyak diburu oleh masyarakat. Selain itu, Indofarma juga menjadi salah satu perusahaan yang bertanggung jawab akan alat kesehatan untuk penanganan Covid-19 di Indonesia seperti impor 100.000 paket rapid test dari China dan Korea.

Industri alat kesehatan dan farmasi merupakan sektor yang masuk kategori high demand. Pemerintah mendorong sektor ini untuk mampu memenuhi permintaan masyarakat terhadap produk-produk kesehatan. Saat ini, kebutuhan produk dari kedua sektor tersebut meningkat seiring penanganan wabah Covid-19. Kondisi ini perlu dimanfaatkan dengan baik, untuk mewujudkan kemandirian Indonesia di sektor kesehatan dan 
farmasi,Tingginya kebutuhan tersebut dapat dilihat dari jumlah obat-obatan maupun alat kesehatan yang telah digunakan untuk mengatasi pandemi Covid-19. Hal ini merupakan capaian positif yang harus dijaga karena saat ini sektor farmasi dan alat kesehatan merupakan kontributor terbesar bagi perekonomian Indonesia.

Selanjutnya, sektor yang dinilai mendapatkan keuntungan di tengah pandemi ini adalah sektor telekomunikasi. Tingkat permintaan data yang meningkat dengan adanya kebijakan belajar dari rumah (study from home), bekerja dari rumah (work from home), dan beribadah di rumah selama masa tanggap darurat penyakit virus corona atau Covid-19. Kebijakan yang menjadi bagian dari upaya menjaga jarak fisik (physical distancing) dan pembatasan sosial berskala besar (PSBB) untuk memutus rantai penularan Covid-19 ini mengakibatkan masyarakat bekerja dan belajar via dunia maya. Akses ke jaringan internet pun terus meningkat seiring makin banyaknya kantor yang meminta karyawan bekerja dari rumah, sekolah yang menyelenggarakan belajar dari rumah, dan juga perkuliahan secara daring. Sejumlah penyedia layanan internet atau internet provider kebanjiran pelanggan baru yang ingin menggunakam layanan mereka untuk menunjang kegiatan dari rumah. Pandemi Covid-19 memaksa banyak orang untuk menjaga jarak fisik dan berdiam diri di rumah. Masyarakat maupun pelaku bisnis yang sebelumnya biasa bertemu secara fisik kini hanya bisa berkomunikasi dengan layanan koneksi internet ataupun telepon selular. Kebijakan pembatasan sosial, bekerja dan belajar di rumah berdampak pada lonjakan trafik data atau internet sebesar 10\% hingga $30 \%$.

Penerapan kebijakan PSBB guna menekan penyebaran virus corona juga ikut memberi andil besar terhadap lonjakan trafik internet. Provinsi DKI Jakarta menjadi wilayah pertama yang menerapkan PSBB, yakni mulai 10 April 2020 selama 14 hari hingga 23 April, dan kemudian diperpanjang 14 hari berikutnya sampai 7 Mei 2020. Kebijakan PSBB ini kemudian diikuti kota/kabupaten di sekitar Jakarta, yakni Kota Depok, Kota Bogor, Kabupaten Bogor, Kota Bekasi, Kabupaten Bekasi, Kota Tangerang, Kota Tangerang Selatan, dan Kabupaten Tangerang. Bahkan, Provinsi Jawa Barat akan menerapkan PSBB yang berlaku bagi semua kabupaten/kota mulai 6 Mei hingga 19 Mei 2020. Di luar itu, sejumlah daerah juga telah memberlakukan PSBB, di antaranya Surabaya. Merespons kondisi tersebut, perusahaan-perusahan telekomunikasi dan penyedia layanan broadband internet telah menyiapkan sejumlah langkah untuk mendukung kebijakan pemerintah. Tingginya trafik data saat ini menjadi momentum bagi operator telekomunikasi dan provider internet untuk meningkatkan kualitas layanan dan ekspansi. Faktor lain yang membuat prospek bisnis sektor telekomunikasi semakin bagus adalah terus meningkatnya jumlah pengguna internet.

Harga saham pada pasar bursa sampai saat ini masih akan dibayangi perkembangan penyebaran Covid-19 yang semakin mengkhawatirkan dari dalam negeri. Adanya perbedaan dampak pandemi covid-19 pada berbagai sektor perekonomian di Indonesia, membuat peneliti tertarik untuk mengkaji hal ini lebih mendalam. Penelitian ini akan melihat dampak pandemi Covid-19 terhadap harga saham pada beberapa sektor Industri yang terdaftar di Bursa Efek Indonesia, dengan metode event studies. Event studies adalah Penelitian yang mengamati dampak dari pengumuman informasi terhadap harga sekuritas. Penelitian event studies umumnya berkaitan dengan seberapa cepat suatu informasi yang masuk ke pasar dapat tercermin pada harga saham (Tandelilin, 2015). Metode event studies yang digunakan dalam penelitian ini adalah untuk mengetahui reaksi pasar modal terhadap adanya pengumuman masuknya Virus Covid-19 ke Indonesia, diberlakukannya kebijakan PSBB dalam rangka menanggulangi pandemic Covid-19, kemudian pada saat pengumuman dijalankannya kembali moda transportasi. Event window yang digunakan dalam penelitian ini adalah 11 hari,dimana 5 hari sebelum dan 5 hari sesudah hari sesudah pengumuman event dan 1 event date pada hari tersebut.

\section{KAJIAN PUSTAKA}

\section{Signalling Theory}

Teori sinyal melandasi penelitian ini, teori sinyal (signalling theory) berawal dari tulisan George Akerlof pada karyanya ditahun 1970 "The Market for Lemons", yang memperkenalkan istilah informasi asimetris (assymetri information). Akerlof (1970) mempelajari fenomena ketidakseimbangan informasi mengenai kualitas produk antara pembeli dan penjual dengan melakukan pengujian terhadap pasar mobil bekas (used car). Teori sinyal digunakan untuk menjelaskan bahwa laporan keuangan digunakan untuk memberikan sinyal positif (good news) maupun sinyal negatif (bad news) kepada pemakainya. Menurut Brigham dan Housten (2011) isyarat atau sinyal adalah tindakan yang diambil manajemen perusahaan yang membentuk petunjuk bagi investor tentang bagaimana manajemen memandang prospek perusahaan. 
Siganalling theory menyatakan pengeluaran investasi memberi sinyal positif tentang pertumbuhan perusahaan dimasa yang akan datang, sehingga meningkatkan harga saham sebagai indikator nilai perusahaan (Brigham dan Houston, 2011). Peningkatan hutang juga dapat diartikan pihak luar tentang kemampuan perusahaan untuk membayar kewajibannya dimasa yang akan datang atau resiko bisnis yang rendah, sehingga penambahan hutang akan memberikan sinyal positif. Hal ini dikarenakan perusahaan yang meningkatkan hutang dapat dipandang sebagai perusahaan yang yakin dengan prospek perusahaan dimasa yang akan datang (Brigham dan Houston, 2011).

Setiap tindakan mengandung informasi merupakan dasar prinsip teori sinyal, hal tersebut disebabkan karena adanya asymetric information. Teori sinyal menjelaskan bahwa manajer memberikan sejumlah sinyal untuk mengurangi asimetri informasi (Wibowo, 2017). Informasi yang dipublikasikan sebagai suatu pengumuman akan memberikan signal bagi investor dalam pengambilan keputusan investasi. Jika pengumuman tersebut mengandung nilai positif, maka diharapkan pasar akan bereaksi pada waktu pengumuman tersebut diterima oleh pasar (Jogiyanto, 2009). Laporan keuangan merupakan salah satu jenis informasi yang dikeluarkan oleh perusahaan yang menjadi sinyal bagi pihak luar perusahaan. Informasi didalam laporan keuangan berkaitan dengan informasi akuntansi yaitu informasi yang berhubungan dengan keuangan perusahaan seperti laporan keuangan dan informasi non-akuntansi yang tidak berkaitan dengan laporan keuangan. Asumsi utama dari teori sinyal ini memberikan ruang bagi investor untuk mengetahui bagaimana keputusan yang akan diambilnya berkaitan dengan reaksi pasar dari pengumuman ataupun peristiwa. Peristiwa atau pengumuman tersebut mengandung informasi yang dapat mempengaruhi nilai perusahaan dan dampaknya terhadap semua perusahaan dipasar modal.

\section{Efficient Market Hypothesis (EMH)}

Pasar modal dikatakan efisien salah satunya jika harga saham mencerminkan keseluruhan dari informasi yang tersedia dipasar. Keseluruhan informasi harus tersedia bagi investor, untuk mengetahui segala sesuatutentang perusahaan dan saham perusahaan. Konsep Efficient Market Hypothesis (EMH) pertama kali dikemukakan oleh Fama (1970) dalam Rahman dan Ervina (2017) yang pada intinya menyatakan bahwa di pasar yang efisien, surat berharga berupa obligasi konversi akan selalu diperdagangkan pada nilai wajarnya (fair value) sehingga tidak seorang pun mampu memperoleh imbal hasil yang tidak normal (abnormal return), setelah disesuaikan dengan risiko, dengan menggunakan strategi perdagangan yang ada. Dengan kata lain, harga yang terbentuk di pasar merupakan hasil refleksi dari seluruh informasi yang tersedia.

Fama (1970) Rahman dan Ervina (2017) melakukan penyesuian atas konsep EMH dengan didukung oleh bukti empiris dan mengelompokan efisiensi pasar kedalam tiga bentuk, yaitu:

a. The Weak Efficient Market Hypothesis

Efisiensi pasar dikatakan lemah (weak-form) karena dalam proses pengambilan keputusan jual-beli saham investor menggunakan data harga dan volume masa lalu. Berdasarkan harga dan volume masa lalu itu berbagai model analisis teknis digunakan untuk menentukan arah harga apakah akan naik atau akan turun. Asumsi yang ada pada hipotesis ini adalah, bahwa harga pasar telah mencerminkan keuangan yang lalu dan dan data-data berupa harga dan volume perdangan dimasa lalu, seharusnya tidak berhubungan dengan keuangan yang akan datang. Jadi investor tidak bisa memperoleh sedikit keuntungan dengan menggunakan trading rules berdasarkan pada informasi masalalu yang terdapat di pasar modal.

b. The Semistrong Efficient Market Hypothesis

Efisiensi pasar dikatakan setengah kuat (semistrong-form) dalam proses pengambilan keputusan jual-beli saham investor menggunakan data harga masa lalu, volume masa lalu, dan semua informasi yang dipublikasikan seperti laporan keuangan, laporan tahunan, pengumuman bursa, informasi keuangan internasional, peraturan perundang-undangan, peristiwa politik, peristiwa hukum, peristiwa sosial, dan lain-lain yang dapat memengaruhi perekonomian nasional. Asumsi yang ada pada hipotesis ini adalah, bahwa pada saat investor mengambil keputusan setelah informasi baru dipublikasikan seharusnya tidak memperoleh keuntungan abnormal karena harga saham telah mencerminkan seluruh informasi yang telah dipublikasikan. Harga saham akan bereaksi dengan cepat dan akurat menyesuaikan ketingkat harga yang baru ketika informasi publik diumumkan.

\section{c. The Strong Efficient Market Hypothesis}

Efisiensi dikatakan kuat (strong-form) karena investor menggunakan data yang lebih lengkap, yaitu harga masa lalu, volume masa lalu, informasi yang dipublikasikan, dan informasi privat yang tidak dipublikasikan secara umum. Kondisi dimana harga saham tidak hanya mencerminkan informasi yang dipublikasikan saja, tetapi juga mencerminkan informasi yang tidak dipublikasikan yang dikenal dengan insider information karena yang mempunyai informasi tersebut adalah pihak yang berada dalam perusahaan. Sehingga tidak ada investor 
yang memperoleh abnormal karena antara investor dan pihak perusahaan memiliki informasi yang sama. 2015):

Ada beberapa kondisi yang harus terpenuhi untuk tercapainya pasar yang efisien yaitu (Hasanuddin,

a. Ada banyak investor yang rasional dan berusaha untuk memaksimalkan profit. Investor-investor tersebut secara aktif berpartisipasi di pasar dengan menganalisis, menilai, dan melakukan perdagangan di pasar.

b. Semua pelaku pasar dapat memperoleh informasi pada saat yang sama dengan cara yang murah dan mudah.

c. Informasi yang terjadi bersifat acak, artinya setiap pengumuman yang terjadi bersifat bebas dan tidak dipengaruhi oleh pengumuman lain

d. Investor bereaksi secara cepat terhadap infomasi baru sehingga harga sekuritas akan berubah sesuai dengan perubahan nilai sebenarnya akibat informasi tersebut.

Perubahan harga dalam suatu pasar yang kompetitif ditentukan oleh besar kecilnya permintaan serta penawaran. Apabila suatu informasi terbaru masuk ke pasar yang berhubungan dengan suatu aktiva, informasi ini akan digunakan untuk menganalisis dan menginterpretasikan nilai dari aktiva bersangkutan. Harga merupakan cerminan dari adanya informasi yang diperoleh pelaku pasar secara menyeluruh, sehingga apabila harga memiliki kandungan informasi maka dapat dikatakan harga yang terbentuk sepenuhnya mencerminkan sistem informasi. Inti dari teori EMH adalah jika informasi tidak terhambat dan tercermin dalam harga saham di pasar, maka harga saham esok hari akan mencerminkan informasi dan berita esok hari dan tidak berhubungan (independen) dengan harga saham hari ini. Implikasi dari teori EMH adalah tidak ada seorang investor pun yang dapat memperoleh imbal hasil yang abnormal (abnormal return) kecuali terdapat gap antara informasi yang ada dan efisiensi di pasar saham. Pada akhirnya, jika suatu pasar tidak efisien, mekanisme harga yang ada tidak dapat menjamin alokasi modal yang efisien di dalam perekonomian yang dapat berdampak negatif terhadap ekonomi secara agregat (Hamid dan Akash, 2010 dalam Rahman dan Ervina (2017).

\section{Teori Event Study}

Robert G. Bowman dalam artikelnya yang berjudul Understanding And Conduction Even Study (1983) mendefinisikan bahwa study peristiwa sebagai suatu yang meneliti tentang perilaku harga sekuritas dalam suatu reaksi pasar dari pengumuman ataupun peristiwa. Peristiwa atau pengumuman tersebut mengandung informasi yang dapat mempengaruhi nilai perusahaan dan dapkaknya terhadap semua perusahaan dipasar modal baik secara sistemikmaupun nonsitemik. Peristiwa atau pengumuman tersebut seperti, peristiwa pengumuman deviden, pemilihan presiden, penerbitan obligasi konversi, peristiwa meledaknya bom bali, pengumuman marger, pengumuman akuisisi, pengumuman stock split, pengumuman laba, pengumuman produk baru dan lain sebagainya, dikutip dari (hartono:2010).

Langkah-langkah analisis penelitian menggunakan teknik event study, yaitu:

a. Menentukan peristiwa yang akan diteliti.

b. Melakukan studi kepustakaan dengan mengumpulkan teori-teori pendukung dan literatur dan penelitianpenelitian terdahulu guna mendapatkan dasar yang diperlukan dalam kajian teori sebagai alternatif pemecahan masalah yang menjadi bahasan dalam penelitian ini.

c. Melakukan dokumentasi melalui finance.yahoo.co.id dan www.idx.co.id guna mengumpulkan data sekunder.

d. Menentukan batasan kriteria perusahaan yang akan diteliti sehingga didapatkan sampel emiten.

e. Event date (t0) dan menentukan periode pengamatan (event windows). Metode event studies yang digunakan dalam penelitian ini adalah untuk mengetahui reaksi pasar modal terhadap adanya pengumuman masuknya Virus Covid-19 ke Indonesia, diberlakukannya kebijakan PSBB dalam rangka menanggulangi pandemic Covid-19, kemudian pada saat pengumuman dijalankannya kembali moda transportasi, dan pada saat hari raya Idul Fitri. Event window yang digunakan dalam penelitian ini adalah 11 hari,dimana 5 hari sebelum dan 5 hari sesudah hari sesudah pengumuman event dan 1 event date pada hari tersebut.

\section{Pasar Modal}

Pasar modal merupakan tempat bertemunya antara penjual dan pembeli dengan risiko untung dan rugi serta sarana perusahaan untuk meningkatkan kebutuhan dana jangka panjang dengan menjual saham satau mengeluarkan obligasi (Jogiyanto,2010:29). Sedangkan menurut Husnan (2001:3) secara formal pasarmodal dapat didefinisikan sebagai pasar untuk berbagai instrumen keuangan jangka panjang yang biasa diperjualbelikan baik dalam bentuk hutang maupun modal sendiri yang diterbitkan oleh pemerintah maupun 
perusahaan. Pasar modal mempunyai peran penting dalam perekonomian terutam dalam pengalokasian dana masyarakat. Pasar modal merupakan sarana perusahaan untuk meningakatkan kebutuhan jangka panjang dengan menjual saham atau mengeluarkan obligasi. Pasar modal juga berfungsi sebagai sarana pengalokasian dana yang produktif untuk memindahkan dana dari pemberi pinjaman ke peminjam. Alokasi tersebut tejadi jika individu yang mempunayi kelebihan dana dapat meminjamkanya ke individu lain yang produktif yang membutuhkan dana.

BAPEPAM membagi peranan dan manfaat pasar modal sebagai berikut:

a. Pasar modal merupakan wahan pengalokasian dana secara efisien.

b. Memungkinkan bagi para investor untuk memiliki perusahaan yang sehat dan prospek baik.

c. Pelaksanaan manajemen perusahaan secara profesional dan transparan.

d. Peningkatan aktiva ekonomi nasiona

\section{Saham}

Saham yaitu tanda bukti pengambilan bagian atau serta dalam suatu perseroan terbatas bagi perusaahaan yang bersangkutan. Saham adalah suatu bentuk model penyertaan (equity capital) atau bukti posisi kepemilikan dalam suatu perusahaan. Banyak saham yang tidak diperdagangkan karena terlalu kecil atau dikendalikan sepenuhnya oleh keluarga. Saham yang bisa dijadikan wahana investasi adalah yang dikenal sebagai emisi yang diperdagangkan secara umum dan dibeli serta dijual pada pasar terbuka (Umam \& Sutanto, 2017). Saham dapat didefinisikan juga sebagai bukti atau sertifikat kepemilikan atau suatu badan terhadap perusahaan yang menerbitkan sekuritas tersebut, yang dapat pula diartikan sebagai keikutsertaan investor sebagai pemodal pada suatu perusahaan, sehingga memiliki hak klaim atas penghasilan dan aktiva perusahaan tersebut. Lebih jauh lagi Fahmi (2018), mengemukakan pengertian saham dalam beberapa pengertian, yaitu :

a. Tanda bukti penyertaan kepemilikan modal/dana pada suatu perusahaan.

b. Kertas yang tercantum dengan jelas nilai nominal, nama perusahaan, dan diikuti dengan hak dan kewajiban yang dijelaskan kepada setiap pemegangnya.

c. Persediaan yang siap untuk dijual.

Saham dibagi ke dalam beberapa jenis. Umam \& Sutanto (2017) memaparkan jenis-jenis saham sebagai berikut.

1) Berdasarkan cara peralihan

a. Saham atas unjuk (bearer stock), yaitu saham yang tidak ditulis nama pemiliknya, agar mudah dipindahtangankan dari satu investor ke investor lain.

b. Saham atas nama (registered stock), yaitu saham yang ditulis dengan jelas siapa pemiliknya. Dengan demikian, cara peralihannya harus melalui prosedur tertentu, yaitu dengan dokumen peralihan dan nama pemiliknya dicatat dalam buku perusahaan yang khusus membuat daftar nama pemegang saham.

2) Berdasarkan manfaatnya

a. Saham biasa, merupakan jenis efek yang paling sering dipergunakan oleh emiten untuk memperoleh dana dari masyarakat dan jenis yang paling popular di pasar modal.

b. Saham preferen, adalah saham yang berbentuk gabungan antara obligasi dan saham biasa. Saham preferen sama dengan saham biasa karena tidak memiliki tanggal jatuh tempo dan juga mewakili kepemilikan dari modal.

\section{Return Saham}

Return saham atau yang biasa disebut dengan return merupakan pembayaran yang diterima karena hak kepemilikannya, ditambah dengan perubahan dalam harga pasar yang dibagi dengan harga awal. Return atau tingkat pengembalian juga dapat didefinisikan sebagai selisih antara jumlah yang diterima dengan jumlah yang diinvestasikan. Return saham merupakan tingkat keuntungan yang diperoleh pemodal atau investor atas investasi yang dilakukan. Return saham atau tingkat pengembalian yang dimaksud adalah tingkat pengembalian untuk saham biasa dan merupakan pembayaran kas yang diterima akibat kepemilikan suatu saham ditambah perubahan harga pasar saham lalu dibagikan dengan harga saham pada saat awal investasi.

Menurut Umam \& Sutanto (2017) faktor-faktor yang mempengaruhi return saham adalah sebagai berikut:

1) Faktor makro, yaitu faktor yang berada pada luar perusahaan, yaitu:

a. Faktor makro ekonomi yang meliputi tingkat bunga umum domestik, tingkat inflasi, kurs valuta asing dan kondisi ekonomi internasional; dan

b. Faktor non ekonomi yang meliputi peristiwa politik dalam negeri, peristiwa politik luar negeri, peperangan, demonstrasi, massa, dan kasus lingkungan hidup. 
2) Faktor mikro adalah faktor yang berada di dalam perusahaan, yaitu:
a. Laba bersih per saham;
b. Nilai buku per saham;
c. Rasio hutang terhadap ekuitas; dan
d. Rasio keuangan lainnya

Return adalah keuntungan yang diperoleh oleh perusahaan, individu, dan institusi dari hasil kebijakan investasi yang dilakukannya (Umam \& Sutanto, 2017). Return dapat dirumuskan sebagai berikut :

Keterangan :

$$
\text { Return Saham }=\frac{P_{t}-P_{t-1}}{P_{t-1}}
$$

$\mathrm{P}_{\mathrm{t}}=$ Harga pasar saham sekarang

$\mathrm{P}_{\mathrm{t}-1}=$ Harga pasar saham periode sebelumnya

Berdasarkan periodisasi yang dipilih dalam penelitian ini dan atas uraian sebelumnya maka kerangka pemikiran teoritis penelitian ini digambarkan sebagai berikut:

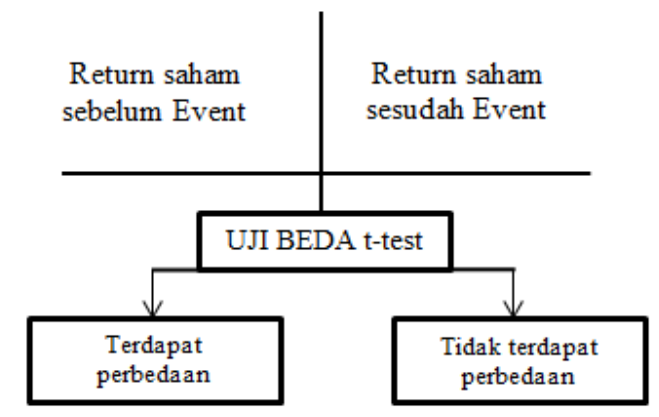

Gambar 4. Rerangka Pemikiran

\section{Hipotesa Penelitian}

$\mathrm{H}_{1}$ : Terdapat perbedaan return saham yang signifikan pada saat sebelum dan setelah pengumuman masuknya Virus Covid-19 di Indonesia pada tanggal 2 Maret 2020

$\mathrm{H}_{2}$ : Terdapat perbedaan return saham yang signifikan pada saat sebelum dan setelah pengumuman di berlakukannya kebijakan PSBB pada tanggal 10 April 2020.

$\mathrm{H}_{3}$ : Terdapat perbedaan return saham yang signifikan pada saat sebelum dan setelah pengumuman dibukanya kembali moda transportasi pada tanggal 7 Mei 2020

\section{METODE}

Populasi dalam penelitian ini adalah perusahaan yang terdaftar di Bursa Efek Indonesia sektor telekomunikasi, industri barang konsumsi dan pariwisata. Pengambilan sampel dilakukan dengan purposive sampling. Teknik ini memilih kelompok target tertentu untuk memperoleh informasi. Sampel ditetapkan untuk tipe-tipe kelompok tertentu yang dapat memberikan informasi yang dibutuhkan karena kelompok tersebut merupakan satu-satunya pihak yang memiliki informasi atau karena kelompok tersebut sesuai dengan kriteria-kriteria yang telah di tetapkan peneliti.

Metode analisis data penelitian ini menggunakan teknik event study. Jogiyanto (2013) menyatakan bahwa studi peristiwa (event study) dapat digunakan untuk menguji kandungan informasi (information content) dari suatu pengumuman dan dapat juga digunakan untuk menguji efesiensi pasar bentuk setengah kuat. Jika pengumuman mengandung informasi (information content), maka diharapkan pasar akan bereaksi pada waktu pengumuman tersebut diterima oleh pasar. Reaksi pasar ditunjukkan dengan adanya perubahan harga dari sekuritas bersangkutan. Metode untuk Event Study umumnya mengikuti prosedur sebagai berikut Elton dan Gruber dalam Munawarah (2009):

1) Mengumpulkan sampel perusahaan yang mempunyai suatu peristiwa yang ingin diteliti.

2) Menentukan dengan tepat hari atau tanggal pengumuman dan menentukan sebagai hari 0 .

3) Menentukan periode penelitian atau event window, 5 hari sesudah dan sebelum tanggal pengumuman,

4) Untuk setiap sampel perusahaan dilihat return dan aktivitas volume perdagangan pada masing-masing satuan periode (hari). 
5) Menghitung abnormal return dari return yang sudah didapatkan untuk setiap perusahaan.

\section{HASIL DAN PEMBAHASAN}

\section{Hasil}

Sebelum meneruskan analisis, instrumen telah diuji normalitas dengan hasil normal dan uji multikolinearitas dengan hasil baik dan tidak ada masalah multikolinearitas, serta telah memenuhi syarat berdasarkan uji heteroskedastisitas. Berikut hasil analisis selanjutnya yang telah dilakukan.

\section{Uji Perbandingan (Paired Samples Test)}

Tabel 1. Paired Samples Test Event Study 2

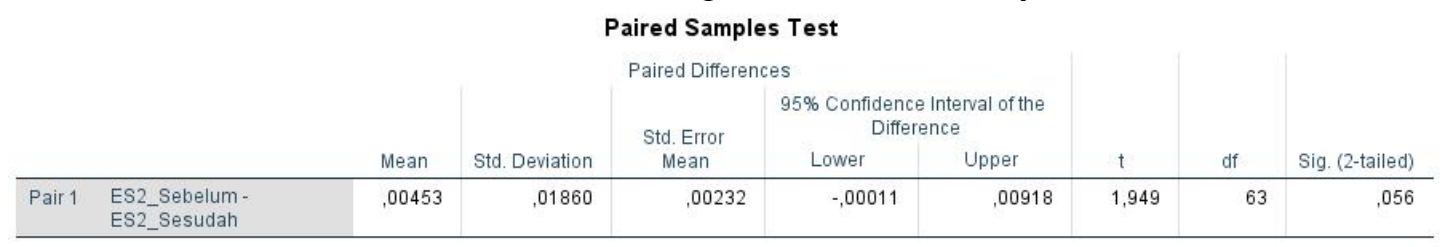

Sumber : data diolah (2020)

Hasil Paired Samples Test menunjukkan Hasil T-Hitung 1.160 dengan Sig 0,056 > 0,05 yang berarti tidak ada pengaruh yang signifikan antara return saham sebelum dan sesudah pemberlakuan PSBB. Hasil pengujian membuktikan bahwa nilai return saham tidak mengalami perubahan secara signifkan setelah pemberlakuan PSBB. Tidak adanya pengaruh yang signifikan terhadap stock return sejak pemberlakuan PSBB ini dapat disebabkan oleh beberapa faktor lain di luar sentimen masyarakat, yang belum dipertimbangkan dalam penelitian ini. Nyatanya, kondisi saham gabungan (IHSG) di Indonesia sudah mulai mengalami penurunan signifikan dari sejak pandemi covid-19. Beberapa kejadian sebelum Pengumuman pemberlakuan PSBB pun sudah mampu mempengaruhi sentimen masyarakat. Masyarakat sudah melihat ketidaktegasan dan in-transparansi pemerintah dalam menanggulangi pandemi covid-19 ini sehingga sudah terbentuk sentimen negatif jauh sebelum pengumuman pemberlakuan PSBB. Variable faktor internal perusahaan sendiri juga mampu mempengaruhi stock return. Onggo (2017) dalam penelitiannya menemukan bahwa return on equity memiliki pengaruh yang besar terhadap stock return perusahaan. Pradrwati (2018) menunjukkan pengaruh signifikan dari book value, return on equity, return on asset, dan earnings per share terhadap stock return.

\section{Event Study 3}

Event Study 3 dilakukan pada saat sebelum dan setelah pengumuman dibukanya kembali moda transportasi pada tanggal 7 Mei 2020. Tabel dan Grafik Saham sebelum dan setelah pengumuman dibukanya kembali moda transportasi sebagai berikut:

Tabel 2. Return Saham Sebelum dan Sesudah Event Study 3

\begin{tabular}{ccccc}
\hline & Periode & $\begin{array}{c}\text { Industri dan } \\
\text { Konsumen }\end{array}$ & Pariwisata & Telekomunikasi \\
\hline 29-Apr-20 & $\mathrm{t}-5$ & 0,01 & 0,00 & 0,02 \\
\hline 30-Apr-20 & $\mathrm{t}-4$ & 0,00 & 0,00 & 0,00 \\
\hline 04-Mei-20 & $\mathrm{t}-3$ & $-0,01$ & 0,00 & $-0,03$ \\
\hline 05-Mei-20 & $\mathrm{t}-2$ & 0,00 & 0,00 & $-0,02$ \\
\hline 06-Mei-20 & $\mathrm{t}-1$ & 0,01 & 0,00 & $-0,03$ \\
\hline $07-M e i-20$ & $\mathrm{t} 0$ & 0,00 & 0,00 & 0,00 \\
\hline 08-Mei-20 & $\mathrm{t}+1$ & 0,00 & 0,01 & $-0,01$ \\
\hline 11-Mei-20 & $\mathrm{t}+2$ & $-0,01$ & 0,00 & 0,00 \\
\hline 12-Mei-20 & $\mathrm{t}+3$ & 0,00 & $-0,01$ & $-0,03$ \\
\hline 13-Mei-20 & $\mathrm{t}+4$ & 0,00 & 0,00 & 0,06 \\
\hline 14-Mei-20 & $\mathrm{t}+5$ & 0,00 & $-0,01$ & 0,04 \\
\hline
\end{tabular}




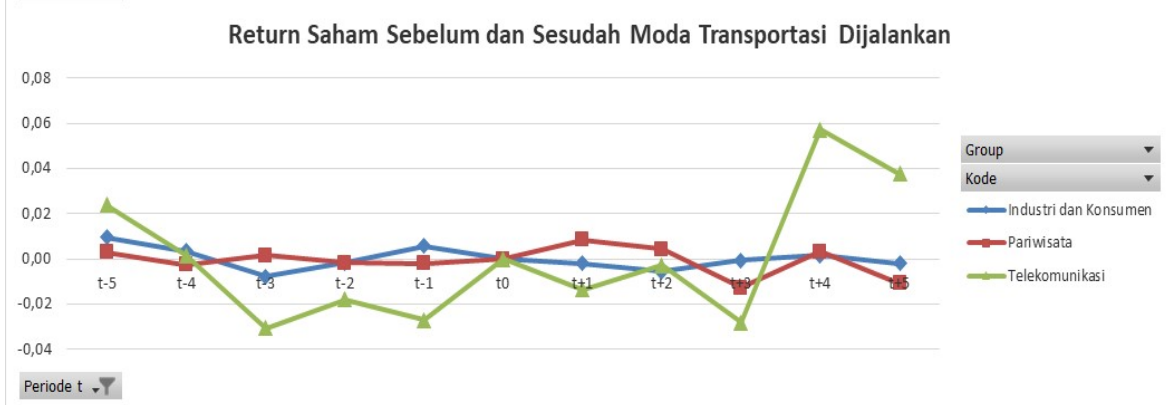

Gambar 5. Return Saham Sebelum dan Sesudah Event Study 3

Tabel 3. Harga Saham Sebelum dan Sesudah Event Study 3

\begin{tabular}{ccccc}
\hline & Periode & $\begin{array}{c}\text { Industri dan } \\
\text { Konsumen }\end{array}$ & Pariwisata & Telekomunikasi \\
\hline 29-Apr-20 & $\mathrm{t}-5$ & 3.325 & 743 & 1.415 \\
\hline 30-Apr-20 & $\mathrm{t}-4$ & 3.325 & 743 & 1.415 \\
\hline 04-Mei-20 & $\mathrm{t}-3$ & 3.274 & 738 & 1.368 \\
\hline 05-Mei-20 & $\mathrm{t}-2$ & 3.278 & 737 & 1.361 \\
\hline 06-Mei-20 & $\mathrm{t}-1$ & 3.246 & 734 & 1.321 \\
\hline 07-Mei-20 & $\mathrm{t} 0$ & 3.246 & 734 & 1.321 \\
\hline 08-Mei-20 & $\mathrm{t}+1$ & 3.221 & 738 & 1.313 \\
\hline 11-Mei-20 & $\mathrm{t}+2$ & 3.215 & 736 & 1.330 \\
\hline 12-Mei-20 & $\mathrm{t}+3$ & 3.218 & 730 & 1.281 \\
\hline 13-Mei-20 & $\mathrm{t}+4$ & 3.226 & 730 & 1.305 \\
\hline 14-Mei-20 & $\mathrm{t}+5$ & 3.282 & 726 & 1.281 \\
\hline
\end{tabular}

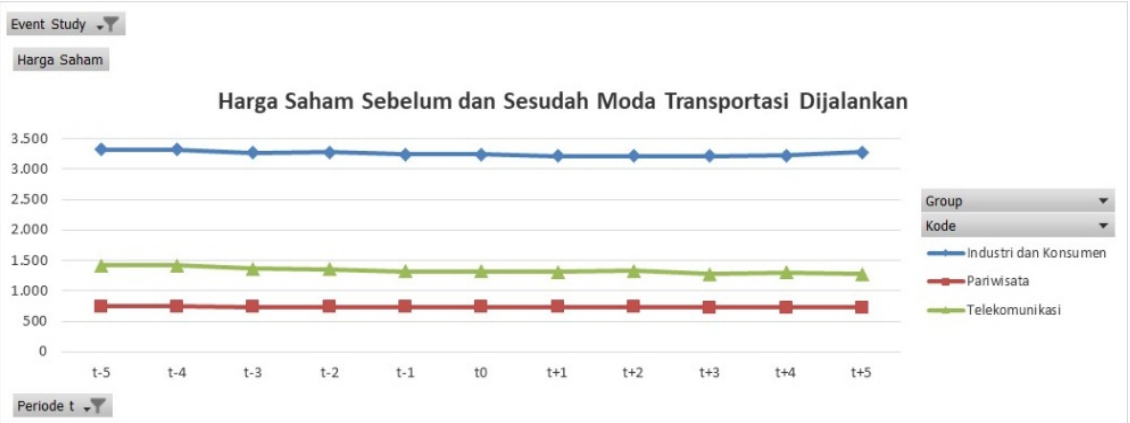

Grafik 6. Harga Saham Sebelum dan Sesudah Event Study 3

\section{Uji Normalitas Data}

Tabel 4. Uji Normalitas Data Event Study 3

\section{Tests of Normality}

\begin{tabular}{ll|l|l|l|r|r|r} 
& & \multicolumn{3}{c}{ Kolmogorov-Smirnov } & \multicolumn{3}{c}{ Shapiro-Wilk } \\
& Indurstri & Statistic & df & Sig. & Statistic & df & Sig. \\
\hline \multirow{2}{*}{ ES3_Sebelum } & Industri &, 259 & 41 &, 000 &, 903 & 41 &, 002 \\
\cline { 2 - 9 } & Pariwisa &, 330 & 17 &, 000 &, 771 & 17 &, 001 \\
\cline { 2 - 9 } & Telekomu &, 307 & 6 &, 080 &, 823 & 6 &, 094 \\
\hline \multirow{2}{*}{ ES3_Sesudah } & Industri &, 340 & 41 &, 000 &, 813 & 41 &, 000 \\
\cline { 2 - 9 } & Pariwisa &, 248 & 17 &, 007 &, 891 & 17 &, 048 \\
\cline { 2 - 9 } & Telekomu &, 422 & 6 &, 001 &, 654 & 6 &, 002 \\
\hline
\end{tabular}

a. Lilliefors Significance Correction

Sumber : data diolah (2020) 
Persyaratan sebelum menguji independent sample t-test yaitu data yang digunakan harus berdistribusi normal. Uji normalitas dapat dilakukan menggunakan uji Kolmogorov-Smirnov dan uji Shapiro-Wilk yang bertujuan untuk mengetahui bahwa data untuk pengujian t-test berdistribusi normal. Kriteria yang digunakan uji Kolmogorov- Smirnov dan uji Shapiro-Wilk adalah jika masing-masing variabel menghasilkan nilai sig. $>$ 0,05 , maka dapat disimpulkan bahwa data pada variabel yang diteliti terdistribusi secara normal. Berdasarkan hasil uji normalitas pada tabel diatas,hasil uji Kolmogorov-Smirnov dan uji Shapiro-Wilk dapat dilihat pada sektor Industri barang konsumsi dan pariwisata data tidak terdistribusi normal, baik pada saaat sebelum event study maupun setelah event study. Pada sektor telekomunikasi data terdistribusi normal, baik pada saaat sebelum event study maupun setelah event study hal ini dapat dilihat dari nilai sig. $>0.05$.

\section{Uji Perbandingan (Paired Samples t-Test)}

Tabel 5. Paired Samples Test Event Study 3

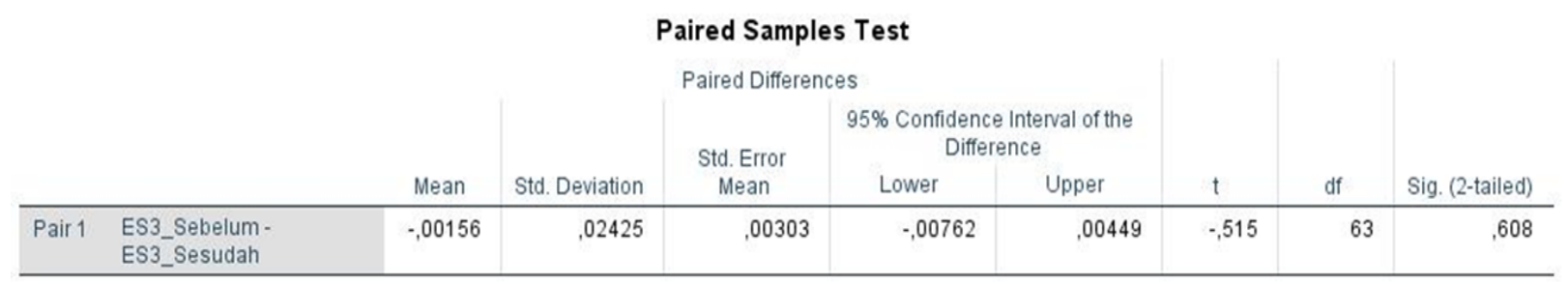

Sumber : data diolah (2020)

Hasil Paired Samples Test menunjukkan Hasil T-Hitung 0,306 dengan Sig 0,760 >0,05 yang berarti tidak ada pengaruh yang signifikan antara return saham sebelum dan sesudah moda transportasi dijalankan. Hasil pengujian membuktikan bahwa nilai return saham tidak mengalami perubahan secara signifkan setelah moda transportasi dijalankan, sama halnya pada saat sebelum dan sesudah pemberlakuan PSBB, masyarakat sudah melihat ketidaktegasan dan in-transparansi pemerintah dalam menanggulangi pandemi Covid-19 ini sehingga sudah terbentuk sentimen negatif. Faktor lain yang menyebabkan tidak adanya pengaruh yang signifikan antara return saham sebelum dan sesudah moda transportasi dijalankan yaitu karena para emiten dinilai sudah mengetahui apa-apa saja yang terjadi dan sudah ada dukungan dari pemerintah berupa stimulusstimulus yang digelontorkan agar dunia usaha tetap dapat bertahan di tengah terjangan pandemi. Selain itu, beberapa perusahaan juga telah melakukan penyesuaian terhadap isu pandemi ini sehingga dampaknya tidak separah bulan Maret, dimana awal pengumuman adanya Covid-19 di Indonesia.

\section{KESIMPLAN DAN SARAN}

\section{Kesimpulan}

Berdasarkan hasil uji statistik terhadap stocks return pada perusahaan yang terdaftar di Bursa Efek Indonesia sektor telekomunikasi, industri barang konsumsi dan pariwisata sebelum dan setelah tanggal pengumuman dapat disimpulkan sebagai berikut :

1) Terdapat perbedaan return saham yang signifikan pada saat sebelum dan setelah pengumuman masuknya Virus Covid-19 di Indonesia pada tanggal 2 Maret 2020

2) Tidak terdapat perbedaan return saham yang signifikan pada saat sebelum dan setelah pengumuman di berlakukannya kebijakan PSBB pada tanggal 10 April 2020

3) Tidak terdapat perbedaan return saham yang signifikan pada saat sebelum dan setelah pengumuman dibukanya kembali moda transportasi pada tanggal 7 Mei 2020

\section{Saran}

Berdasarkan simpulan yang telah dijelaskan, maka peneliti memberikan saran-saran sebagai berikut:

1) Bagi investor, di masa pandemi Covid-19 peneliti menyarankan untuk berinvestasi pada produk-produk yang lebih konservatif agar dapat menghindari fluktuasi hingga menunggu kondisi pasar yang lebih kondusif. Investor bisa memilih investasi di produk reksa dana pasar uang yang pergerakannya lebih stabil 
dan masih tetap tumbuh positif selama pandemi. Reksa dana pasar uang juga bisa dijadikan alternatif untuk dana darurat.

2) Bagi penelitian selanjutnya diharapkan dapat mengembangkan penelitian ini denganmenggunakan metode perhitungan abnormal return lainnya seperti CAPM, dan Market model. Selain itu juga disarankan untuk menggunakan corporate action lainnya seperti right issue, penerbitan warrant, pemeringkatan obligasi, akuisisi dan merger.

\section{REFERENCES}

Cahyaningdyah, D. (2010). Analisis Monday Effect Dan Rogalski Effect Di Bursa Efek Jakarta. JDM , 1 (2), 154-168.

Fahmi, I. (2013). Penganar Pasar Modal. Bandung: Alfabeta, Cv.

Ferita, D. (2018). Analisis Anomali Pasar Terhdapa Return Saham Lq 45 Di Bursa Efek Indonesia : Pengujian Day Of The Week Effect, Weekend Effect, Week Four Effect Dan Rogalsky Effect. Jom Feb , $1(1), 1-15$.

Gava Media. Putri, S,. \& Fauzie, S. (2014). Analisis Monday Effect dan Rogalski Effect Terhadap Return Saham Di Bursa Efek Indonesia (BEI) Periode 2012- 2013. Jurnal Ekonomi Dan Keuangan , 2 (11), 685-699.

Gumanti, T. A. (2011). Manajemen Investasi Konsep, Teori Dan Aplikasi. Jakarta: Mitra Wacana Media.

Harsono, B. (2013). Efektif Bermain Saham. Jakarta: Pt Elex Media Komputindo Kompas Gramedia.

Hikmawati, F. (2017). Metode Penelitian. Depok: Pt Rajagrafindo Persada.

Jogiyanto. (2017). Teori Portofolio Dan Analisis Investasi. Yogyakarta: Bpfe Yogyakarta.

Kartikaningsih, Dewi. 2020. Pengaruh Nilai Tukar Terhadap Harga Saham Perusahaan Sektor Food And Beverage Di Masa Pandemi Covid-19 Bisma: Jurnal Bisnis dan Manajemen p-ISSN 1978-3108,eISSN2623-0879 Vol. 14 No. 2, 2020, Hal. 133-139

Kasdjan, A. M., Nazarudin, \& Yusuf, J. (2017). Pengaruh Anomali Pasar Terhadap Return Saham Perusahaan Lq-45. Jurnal Kajian Akuntansi , 1 (1), 35-48.

Khaerul Umam, H. S. (2017). Manajemen Investasi. Bandung: Pustaka Setia.

Khoiriah, Monita; Moh. Amin; Arista Fauzi Kartikasari.2020. Pengaruh Sebelum Dan Saat Adanya Pandemi Covid-19 Terhadap Saham LQ-45 Di Bursa Efek Indonesia Tahun 2020 . E-JRA Vol. 09 No. 11 Agustus 2020 Fakultas Ekonomi dan Bisnis Universitas Islam Malang.

Kristiawan, A. (2010). Analisis Return Jumat Dan Return Senin Pada Indeks Likuiditas 45 Di Bursa Efek Jakarta. Jurnal Akuntansi, Manajemen Bisnis Dan Sektor Publik (Jambsp) , 7 (1), 46-62.

Kusnandar, D., \& Bintari, V. (2020). Perbandingan Abnormal Return Saham Sebelum dan Sesudah Perubahan Waktu Perdagangan Selama Pandemi Covid-19.Jurnal Pasar Modal Dan Bisnis,2(2), 195-202

Lestari, Made Irma (2020). Signifikansi Pengaruh Sentimen Pemberlakuan PSBB Terhadap Aspek Ekonomi: Pengaruh Pada Nilai Tukar Rupiahdan Stock Return(Studi Kasus Pandemi Covid-19. Jurnal Bina Akuntansi, 7(2), 223-239. Retrieved from https://wiyatamandala.e-journal.id/JBA/article/view/98

Muhammad, Radian;, Brady Rikumahu; Aldilla Iradianty. 2016. Pengaruh Weekday Effect Dan Week-Four Effect Terhadap Return Saham Indeks Kompas100 Di Bursa Efek Indonesia Periode 2007 - 2015. eProceeding of Management : Vol.3, No.1 April 2016 | Page 124

Nuraini, F. (2016). Analisis Anomali Pasar Hari Perdagangan Pada Return Saham:. E-Proceeding Of Management, 3 (3), 3147

Nurmasari, Ifa. 2020. Dampak Covid-19 Terhadap Perubahan Harga Saham dan Volume Transaksi (Studi Kasus Pada PT. Ramayana Lestari Sentosa, Tbk.) JURNAL SEKURITAS (Saham, Ekonomi, Keuangan dan Investasi ) Vol.3, No. 3, Mei 2020 Halaman : 230 - 236 LPPM \& Prodi Manajemen Unversitas Pamulang

Paresh Kumar Narayan, Dinh Hoang Bach Phan and Guangqiang Liu. 2020. COVID-19 lockdowns, stimulus packages, travel bans, and stock returns Finance Research Letters, https://doi.org/10.1016/j.frl.2020.101732

Paskalis, F. P. (2016). Semakin Dekat Dengan Pasar Modal Indonesia. Yogyakarta: Deepublish.

Priyatno, D. (2016). Belajar Alat Analisis Data Dan Cara Pengolahannya Dengan SPSS. Yogyakarta:

Roseliani, B., \& Khairunnisa. (2015). Efek Anomali Pasar Terhadap Return Saham (Perusahaan Lq 45 Yang Terdaftar Di Bursa Efek Indonesia Periode 2013). E-Proceeding Of Management , 2 (2), 1649. 
Sadalia, I., \& Pandiangan, O. (2010). Analisis Anomali Pasar Perdagangan Pada Return Saham Di Bursa Efek Indonesia. Jurnal Ekonom , 13 (2), 71-79.

Sari, T. I., \& Susilawati, S. (2018). Analisis Monday Effect, Weekend Effect Dan Pengaruh Hari Perdagangan Terhadap Return Saham Pada Kelompok Saham Indeks Lq 45 Di Bursa Efek Indonesia Periode Februari 2017- Januari 2018. 2 (2), 125-129.

Scott R Baker, Nicholas Bloom, Steven J Davis, Kyle Kost, Marco Sammon, Tasaneeya Viratyosin. 2020. The Unprecedented Stock Market Reaction to COVID-19, The Review of Asset Pricing Studies, ,https://doi.org/10.1093/rapstu/raaa008

Sutedi, A. (2013). Pasar Modal: Mengenal Nasabah Sebagai Pencegahan Pencucian Uang. Bandung: Alfabeta CV.

Tendelilin. (2010). Portofolio Dan Investasi. Yogyakarta: Kanisius.

Trisnadi, M. M., \& Sedana, I. B. (2016). Pengujian Anomali Pasar : Day Of The Week Effect Pada Saham Lq 45 Di Bursa Efek Indonesia. E-Jurnal Manajemen Unud , 5 (6), 3794-3820.

Umam, K., \& Sutanto, H. (2017). Manajemen Investasi. Bandung: Pustaka Setia. 